\title{
Binding of Anti-Double Stranded (ds) DNA-Positive Sera to Denatured (d) DNA and Synthetic Poly[dA-dT] $\times$ Poly[dA-dT] Double Stranded Copolymer in an ELISA Format
}

\author{
Drago Batinić ${ }^{1}$,Marijana Božićević ${ }^{1}$,Ana Krstulović ${ }^{1}$ Dubravka Bosnićc ${ }^{2}$ Mirna Sentić ${ }^{2}$, Jasenka Markeljević2 \\ Branko Malenica ${ }^{1}$, Nada Čikeš ${ }^{2}$ and Matko Marušić ${ }^{1}$
}

1 Division of Immunology, Clinical Department of Laboratory Diagnosis

2 Division of Clinical Immunology and Rheumatology University Hospital Center Zagreb and School of Medicine, Zagreb, Croatia

Summary: Using an ELISA assay anti-nuclear antibody-positive sera from 300 patients with various immunerelated diseases and 64 anti-nuclear antibody-negative sera were analysed for binding to S1-nuclease-treated double stranded (ds) DNA. In addition, the pattern of reactivity of 50 selected anti-dsDNA-positive sera was established using denatured (d) DNA and poly[dA-dT] $\times$ poly[dA-dT] double-stranded alternating copolymer (dAT) as additional DNA antigens. None of the 64 anti-nuclear antibody-negative sera and 76 of the 300 anti-nuclear antibodypositive sera $(25 \%)$ were anti-dsDNA-positive. Of the anti-nuclear antibody-positive and anti-dsDNA-positive sera, $48(63 \%)$ were from systemic lupus erythematosus patients, and 7 (9\%) from rheumatoid arthritis patients, whereas 21 patients $(27.6 \%)$ suffered from various immune and non-immune related diseases. Anti-dsDNA-positive reactivity was highly correlated with dDNA and dAT reactivity $(r=0.906, p<0.0001$ and $r=0.93, p<0.0001$, respectively). Although the majority of the 50 selected ( 37 systemic lupus erythematosus and 13 non-systemic lupus erythematosus) anti-dsDNA-positive sera concomitantly bound to both additional antigens, 7 of these (14\%) did not bind to dAT, and $2(4 \%)$ did not bind to dDNA. Anti-dsDNA-positive sera $(n=37)$ showed a similar pattern, in which $8.1 \%$ and $2.7 \%$ of sera did not bind to dAT and to dDNA, respectively. In contrast, anti-dsDNA-negative sera from various immune-related diseases bound either ssDNA (12.5\%) or dDNA and dAT (12.5\%). These data suggest that dsDNA and dAT-based assays detect similar but not identical specificities in the sera of patients suffering from systemic lupus erythematosus and in a proportion of non-systemic lupus erythematosus patients.

\section{Introduction}

Antibodies against double stranded (ds) DNA are found in $50 \%$ to $75 \%$ of patients with systemic lupus erythematosus, and they represent one of the most helpful markers for diagnosing systemic lupus erythematosus (reviewed in 1.c. (1)). In addition to their diagnostic potential, these antibodies are associated with the development of renal complications in systemic lupus erythematosus patients (2). Although anti-dsDNA ${ }^{1}$ ) antibodies are a central feature of systemic lupus erythematosus and are thought to play a role in its pathology, they have also been found with lower frequency and in lower titre in normal sera and in sera from patients with other autoimmune diseases $(1-4)$. In contrast, antibodies to single-stranded (or denatured) DNA (dDNA $\left.{ }^{1}\right)$ ) occur in a

\section{1) Abbreviations:}

$\mathrm{dAT}$, poly[dA-dT] $\times$ poly[dA-dT] double-stranded alternating copolymer;

dsDNA, double-stranded deoxyribonucleic acid;

dDNA, denatured DNA;

ssDNA, single stranded DNA. variety of diseases and have no diagnostic importance (4). An intriguing hypothesis has been proposed that low-affinity anti-ssDNA ${ }^{1}$ ) arise as a by-product of polyclonal activation during initial stages of systemic lupus erythematosus, whereas anti-dsDNA antibodies emerge during disease progression by the process of antigendriven selection of B-cells (5).

DNA is a rather flexible molecule that may adopt different conformational forms $(2,6,7)$. Even purified dsDNA (which constitutes $85 \%$ of native DNA extracted from cells) can take up different conformations, and further variations can be induced by temperature, $\mathrm{pH}$ and ion concentration. Thus, these conditions may influence the binding of antibodies to their target antigen (7). Early observations revealed that sera from systemic lupus erythematosus patients reacted with ssDNA, dsDNA or with both forms, but the analysis of the fine specificity of DNA by monoclonal antibodies showed an extremely diverse fine specificity of DNA antibodies (8). It is well appreciated that anti-dsDNA antibodies have little specificity for base sequences $(1,8)$ and bind 
to the epitopes centred on the phosphate backbone of the dsDNA. In contrast, the anti-DNA antibodies reactive with bases are found primarily among antibodies reactive with ssDNA or denatured DNA, where the bases are exposed (7).

ELISA is one of the most adequate techniques for the clinical measurement of the anti-dsDNA level (9). However, since preparing and maintaining an antigenically pure dsDNA is not an easy task in the routine determination of anti-sDNA, synthetic molecules, such as alternating double stranded $\mathrm{dAT}^{1}$ ) copolymer, were proposed as model molecules for an additional anti-native DNA assay ((10) and reviewed in 1.c. (11)). The rationale was the observed high correlation between native DNA and dAT-binding and the absence of contaminating molecules in the synthetic antigen (10). However, others have shown that systemic lupus erythematosus serum may have antibodies against different native DNA epitopes, i. e. those against the structure found in native DNA and those found in synthetic antigen (double helical configuration) (revieived in 1.c. (11)). In this study, we report a solid-phase assay for determination of antibodies against DNA and compare the results obtained using three different antigen preparations.

\section{Materials and Methods}

Control group

This group consisted of 64 adult ( $>15$ years of age) individuals of both sexes $(\hat{\sigma}: q 1: 2)$, whose sera gave a negative reaction for anti-nuclear antibodies in the immunofluorescent assay on rat liver sections. In general, these samples showed no abnormal findings during routine checking of immunological quantities, including total haemolytic activity, C3, C4, Clq, circulating immunocomplexes, rheumatoid-factor, anti-nuclear antibodies, anti-neutrophil cytoplasm antibodies and C-reactive protein.

\section{Study group}

These subjects were selected on the basis of their positive antinuclear antibody reaction (serum dilution $>1: 16$ ) and consisted of 300 adult subjects of both sexes with a male : female ratio of $1: 4.8$. Immunological testing was performed either as part of an out-patient diagnostic procedure or during hospitalisation of patients for treatment at the University Hospital Centre, Zagreb. This group consisted of patients with various diagnoses of autoimmune and non-autoimmune conditions, including degenerative, inflammatory and malignant diseases. All patients with autoimmune diseases were classified and diagnosed according to standard criteria (American Rheumatology Association criteria) (12-14). Patients with autoimmune diseases were either in active or inactive phase of disease. In order to avoid any bias toward a particular diagnosis, the sera were tested blindly, without prior knowledge of the patient's diagnosis. After the results of the ELISA were known, the diagnoses were obtained from responsible physicians, and sera from dsDNA ${ }^{+}$patients were checked in the DNA ELISA.

\section{Sera}

All samples were centrifuged immediately after receipt, heated $(30$ $\min$ at $\left.56^{\circ} \mathrm{C}\right)$ and stored at $-20^{\circ} \mathrm{C}(4-6$ weeks $)$ or at $-70^{\circ} \mathrm{C}$ ( $>6$ weeks).

\section{Anti-nuclear antibody testing}

The test was performed on acetone-fixed rat liver sections using FITC-labelled goat anti-human polyvalent $\lg (\mathrm{A}+\mathrm{G}+\mathrm{M})$ (Imunološki Zavod, Zagreb, Croatia) as a second layer. The slides were analysed under a fluorescence microscope (Carl Zeiss, Jena, Germany) equipped with an epi-illuminator.

\section{Immunoblot-assay for autoantigen's}

In the majority of patients, a panel for the detection of autoantigens (ANA, dsDNA, SS/A, SS/B, Sm/RNP) ${ }^{2}$ ) was performed using an ImmunoDot assay (Gen Bio, San Diego, CA, USA).

\section{Reagents and materials}

Deoxyribonucleic acid from calf thymus (Sigma, Cat. \#D3664), polydeoxyadenylic-thymidylic acid (poly[dA-dT] $\times$ poly[dA-dT]) (Cat. \#P0883), methylated bovine serum albumin (Cat. \#A-1009), nuclease-S1 from Aspergillus oryzae (Cat. \#N7385), calf serum (Cat. \#C6278), bovine serum albumin (Cat. \#A2153), affinitypurified and alkaline phosphatase-conjugated anti-human polyvalent immunoglobulins ( $\alpha, \gamma$ and $\mu$-chain specific) (Cat. \#A5034), polyoxyethylenesorbitan (Tween-20 (Cat. \#P2690)) and p-nitrophenyl phosphate disodium (Cat. \#N2765) were purchased from Sigma, USA. All other chemicals - $\mathrm{NaCl}$, sodium acetate $\left(\mathrm{CH}_{3} \mathrm{CO}_{2} \mathrm{Na}\right), \mathrm{NaOH}, \mathrm{ZnCl}$, ethanolamine $\left(\mathrm{H}_{2} \mathrm{NCH}_{2} \mathrm{CH}_{2} \mathrm{OH}\right)$ and $\mathrm{NaH}_{2} \mathrm{PO}_{4} \times 2 \mathrm{H}_{2} \mathrm{O}$ - were purchased from Kemika, Zagreb, Croatia. The 96-well microtitre assay plates included Falcon PVC Microtest III (Cat. \#3912) and PRO-BIND plates (Cat. \#3915) (Becton Dickinson and Co., Oxnard, Canada) and 96-well flat bottomed plates from Behringwerke AG, Marburg, Germany. The absorbance was read using a Behring ELISA Processor (Behringwerke AG, Marburg, Germany).

\section{Preparation of dsDNA}

Double stranded DNA was prepared according to the original method of Rubin (15). Briefly, native DNA from calf thymus was dialysed against acetate buffer $(0.03 \mathrm{~mol} / \mathrm{l}$ sodium acetate, 0.1 $\mathrm{mol} / \mathrm{l} \mathrm{NaCl}, 5 \mathrm{mmol} / 1 \mathrm{ZnCl}_{2}, 0.1 \mathrm{~g} / \mathrm{l}$ bovine serum albumin, $\mathrm{pH}$ 4.4) and digested with S1-nuclease (0.1 U/ $\mu \mathrm{g} \mathrm{DNA})$ for $3 \mathrm{~h}$ at $37^{\circ} \mathrm{C}$. After dialysis against phosphate-buffered saline (pH 7.2) at $4^{\circ} \mathrm{C}$, the concentration of DNA was determined $\left(A_{260 \mathrm{~nm}}=1\right.$ equals $50 \mathrm{mg} / \mathrm{l})(15)$ and adjusted to $10 \mathrm{mg} / \mathrm{l}$ in phosphate-buffered saline. Before coating with DNA, the wells of the microtitre plate were first coated overnight at $4^{\circ} \mathrm{C}$ with methylated bovine serum albumin ( $10 \mathrm{mg} / \mathrm{l}$ in phosphate-buffered saline $0.1 \mathrm{ml} /$ well). After washing with phosphate-buffered saline, $0.1 \mathrm{ml}$ of DNA solution (10 mg/l in phosphate-buffered saline) was added to each well and the plate was further incubated overnight at $4^{\circ} \mathrm{C}$. The wells were then washed three times with phosphate-buffered saline, filled with $1 \mathrm{~g} / \mathrm{l}$ gelatin in phosphate-buffered saline and incubated overnight at $4^{\circ} \mathrm{C}$. After washing, DNA adhering to wells was redigested with $3 \mathrm{kU} / \mathrm{l}$ of $\mathrm{Sl}$-nuclease in phosphate-buffered saline $(2 \mathrm{~h}$, room temperature), followed by two washes with phosphate-buffered saline $0.5 \mathrm{~g} / 1$ Tween-20.

\section{Preparation of denatured DNA}

Denatured DNA was prepared by heating the DNA solution in a boiling water bath for 15 minutes, then cooling rapidly by immersion in an ice water bath (3). After coating the wells which had been pre-treated with methylated bovine serum albumin, the procedure was continued as described for dsDNA.

\section{Preparation of synthetic antigen}

Poly([dA-dT] $\times$ poly[dA-dT]) was dissolved at $10 \mathrm{mg} / \mathrm{l}$ in phosphate-buffered saline and $0.1 \mathrm{ml}$ was added to each well precoated

2) ANA, anti-nuclear antibody;

dsDNA, double stranded deoxyribonucleic acid;

SS, Sjörgen's syndrome;

$\mathrm{Sm} / \mathrm{RNP}$, small ribonucleoprotein. 
with methylated bovine serum albumin. The procedure was then as described for dsDNA, including S1-nuclease treatment in situ.

\section{Enzyme-linked immunosorbent assay}

Sera were diluted $1: 400$ in phosphate-buffered saline containing $5 \mathrm{~g} /, 1 \mathrm{~g} / \mathrm{g}$ gelatin and $0.5 \mathrm{~g} /$ Tween-20, then $0.1 \mathrm{ml}$ of diluted serum was added per well (in triplicate for each serum). After incubation for $2 \mathrm{~h}$ at room temperature, the wells were washed three times with phosphate-buffered saline $0.5 \mathrm{~g} /$ Tween- 20 , then $0.1 \mathrm{ml}$ of alkaline phosphatase-conjugated affinity-purified anti-human $\mathrm{Ig}$ ( $a, \gamma$, and $\mu$-chain specific) at $1: 5000$ was added to each well. After additional incubation for $2 \mathrm{~h}$ at room temperature, the wells were washed and $0.1 \mathrm{ml}$ of $p$-nitrophenyl phosphate disodium ( $1 \mathrm{~g} / \mathrm{l}$ in ethanolamine buffer, $\mathrm{pH}$ 9.6) was added to each well. The reaction was stopped with $3 \mathrm{~mol} / \mathrm{NaOH}$ and the absorbance read at $405 \mathrm{~nm}$ in a Behring ELISA Processor. The results of the triplicate samples were reported according to the equation:

$$
\text { Fraction bound }=\frac{\text { mean } A_{260 \mathrm{~nm} \text { (lest serum) }}}{\text { mean } A_{260 \mathrm{~nm} \text { (control) }}+3 \mathrm{SD}_{\text {(control) }}}
$$

Control sera were obtained from 10 healthy subjects of both sexes with normal laboratory findings, and were used throughout the study. Positive control of the test was an anti-nuclear antibodypositive serum (titre $1: 1024)$ from a patient with an active systemic lupus erythematosus (M. LJ.) that strongly reacted with dsDNA in an ImmunoDot assay (Gen Bio, San Diego, CA, USA).

\section{Statistics}

Data were analysed using a computer statistical package NCSS, version 5.0, 10/87 (Dr. Jerry L. Hintze, Kaysvile, UT, USA.). The statistics included parametric and non-parametric analysis for testing of the differences between the groups.

\section{Results}

Our preliminary experiments revealed significantly higher absorbance values for microtitre wells pre-coated with methylated-bovine serum albumin to support DNA binding $(\mathrm{p}<0.05)$, and significantly weaker binding of sera to dsDNA redigested with S1-nuclease immediately before running the test $(p<0.01)$ (data not shown). In the final dsDNA ELISA protocol (PVC Microtest III plates, methylated-bovine serum albumin precoating and S1-nuclease redigestion of DNA in situ), the coefficient of variation between triplicate samples was $4.9 \%$, with a high correlation of results obtained with the same sera run on two separate plates $(r=0.941, p<0.0001)$.

None of the anti-nuclear antibody-negative subjects in this study had a detectable level of anti-dsDNA, whereas 76 of $300(25.3 \%)$ anti-nuclear antibody-positive subjects had anti-dsDNA as judged by the sera reactivity of 3 S.D. above the mean of six control human sera run on each plate (tab. 1). Among these, systemic lupus erythematosus (both active and inactive) was the most frequent diagnosis ( $48 / 77$ or $63.2 \%$ ), including 3 patients in which a systemic lupus erythematosus was associated with rheumatoid arthritis and/or vasculitis ("overlapping syndrome") and four patients (5.2\%) provisionally diagnosed as suspected systemic lupus erythematosus. In the non-systemic lupus erythematosus group of patients, rheumatoid arthritis was the most frequent diagnosis
(7/77, 9.1\%), followed by Sjögren's syndrome (2/77, $2.6 \%$ ) and patients suffering from various autoimmunerelated, malignant and inflammatory diseases. As seen from table 1 , most of the systemic lupus erythematosus sera had higher median reactivity $(188 \%)$ than rheumatoid arthritis (151\%) or those from other non-systemic lupus erythematosus patients $(155 \%)$, but the difference was not statistically significant.

Using a cut-off level of 3 S.D. above the mean of normal human sera, the specificity of the assay after testing 64 control anti-nuclear antibody-negative sera was $100 \%$. Taking into account all non-systemic lupus erythematosus subjects with a positive anti-nuclear antibody finding, the specificity of the assay was $82 \%$, but this figure reached $91 \%$ after including anti-nuclear antibody-negative sera. The sensitivity of the assay in the anti-nuclear antibody-positive systemic lupus erythematosus group with both active and inactive disease (including patients with overlapping syndromes, i.e. systemic lupus erythematosus with rheumatoid arthritis and/or vasculitis) was $66 \%$.

By comparing the reactivities of 50 dsDNA-positive sera to different DNA preparations at the same coating concentrations, a high correlation was found between the binding of sera to dsDNA and dDNA ( $r=0.906$, $p<0.0001)$, dsDNA and dAT $(r=0.930, p<0.0001)$ and between dDNA and dAT $(r=0.892, p<0.0001)$

Tab. 1 Anti-nuclear antibody-positive diseases with a positive anti-dsDNA result

\begin{tabular}{|c|c|c|c|}
\hline \multirow[t]{2}{*}{ Diagnosis } & \multirow[t]{2}{*}{$\mathbf{n}$} & \multicolumn{2}{|c|}{$\begin{array}{l}\text { Reactivity with } \\
\text { dsDNA } \\
(\% \text { control })^{2}\end{array}$} \\
\hline & & Median & Range \\
\hline $\begin{array}{l}\text { Systemic lupus erythematosus } \\
\text { "Collagenosis"c } \\
\text { Rheumatoid arthritis } \\
\text { Sjörgen syndrome } \\
\text { M. Wegener } \\
\text { Vasculitis } \\
\text { CREST syndrome } \\
\text { Mixed connective tissue disease } \\
\text { Polymyositis/scleroderma } \\
\text { Polymyositis/vasculitis } \\
\text { M. Beçhet }\end{array}$ & $\begin{array}{r}48 \\
4 \\
7 \\
2 \\
1 \\
1 \\
1 \\
1 \\
1 \\
1 \\
1\end{array}$ & $\begin{array}{l}188 \\
152 \\
151 \\
150 \\
(757) \\
(136) \\
(127) \\
(104) \\
(118) \\
(137) \\
(124)\end{array}$ & $\begin{array}{l}110-924 \\
117-405 \\
121-352 \\
131-169\end{array}$ \\
\hline $\begin{array}{l}\text { Others: } \\
\text { Arthropathy } \\
\text { Spondylarthritis } \\
\text { M. Hodgkin } \\
\text { Lymphadenopathy } \\
\text { Nephrotic syndrome } \\
\text { M. Crohn }\end{array}$ & $\begin{array}{l}1 \\
1 \\
1 \\
1 \\
1 \\
1\end{array}$ & $\begin{array}{l}(110) \\
(218) \\
(292) \\
(109) \\
(157) \\
(108)\end{array}$ & \\
\hline Lost from the study & 2 & 172 & $118-225$ \\
\hline
\end{tabular}

a In relation to 3 S. D. above the mean of normal human sera.

b Including three patients with an overlapping syndrome, i. e. systemic lupus erythematosus in association with rheumatoid arthritis and/or vasculitis.

c Provisonal diagnosis (under verification). 
(tab. 2). However, by comparing the binding of individual sera to different DNA preparations, a significantly higher reactivity to dsDNA than to dDNA (mean, 203\% vs $179 \%, p<0.005$ ) and to dAT (mean, $203 \%$ vs $180 \%$, $\mathrm{p}<0.001$ ) was found. At the same time, there was no difference in the reactivity level of individual sera to dDNA and to dAT $(p=0.7)$ (tab. 2).

Although the majority of 50 selected anti-dsDNA-positive sera ( 37 from systemic lupus erythematosus and 13 from non-systemic lupus erythematosus patients) bound to dDNA and dAT, 7 of 50 (14\%) did not bind to dAT, whereas 2 of $50(4 \%)$ did not bind to dDNA (tab. 3). Anti-dsDNA-positive systemic lupus erythematosus sera ( $\mathrm{n}=37$ ) showed a similar pattern with $8.1 \%$ and $2.7 \%$ of sera lacking the reactivity towards $\mathrm{dAT}$ and to $\mathrm{dDNA}$, respectively. In contrast, the majority (18/24 or $75 \%)$ of anti-dsDNA-negative sera from various diseases were negative for all three antigens: $3 / 24$ (12.5\% bound to dDNA only ( 1 systemic lupus erythematosus and 2 rheumatoid arthritis patients), whereas $3 / 24$ (12.5\%) of nonsystemic lupus erythematosus sera bound to dDNA and to dAT (tab. 3).

Tab. 2 Comparison of reactivity of 50 anti-dsDNA-positive sera to IDNA, dsDNA and DAT in an ELISA assay

\begin{tabular}{|c|c|c|c|c|}
\hline \multirow[t]{3}{*}{ Antigens } & \multicolumn{4}{|c|}{ Serum reactivity to DNA antigens $\mathbf{s}^{\mathbf{a}}$} \\
\hline & \multicolumn{2}{|c|}{ Correlation } & \multirow{2}{*}{$\begin{array}{l}\text { Fraction } \\
\text { bound } \\
(\bar{x} \pm \text { S.D. })\end{array}$} & \multirow{2}{*}{$\begin{array}{l}\text { Difference }^{c} \\
\mathrm{p}\end{array}$} \\
\hline & $\mathrm{r}$ & $\mathrm{p}$ & & \\
\hline $\begin{array}{l}\text { dDNA vs } \\
\text { dAT }\end{array}$ & 0.89 & 0.001 & $\begin{array}{l}1.79 \pm 0.42 \\
1.80 \pm 0.58\end{array}$ & NS \\
\hline $\begin{array}{l}\text { dDNA vs } \\
\text { dsDNA }\end{array}$ & 0.91 & 0.001 & $\begin{array}{l}1.79 \pm 0.42 \\
2.03 \pm 0.55\end{array}$ & $<0.005$ \\
\hline $\begin{array}{l}\text { dsDNA vs } \\
\text { dAT }\end{array}$ & 0.93 & 0.001 & $\begin{array}{l}2.03 \pm 0.55 \\
1.80 \pm 0.58\end{array}$ & $<0.001$ \\
\hline
\end{tabular}

a dsDNA, double stranded DNA; dDNA, denatured DNA; dAT, poly[dA-dT] double stranded alternating copolymer.

b In relation to 3 S. D. above the mean of normal human sera.

c Paired T-test.

Tab. 3 Pattern of anti-nuclear antibody-positive sera binding to DNA antigens

\begin{tabular}{lllll}
\hline Sera & \multicolumn{3}{l}{$\begin{array}{l}\text { Anti-nuclear antibody- } \\
\text { positive sera binding to: }\end{array}$} \\
\cline { 2 - 5 } & $\begin{array}{l}\text { dDNA } \\
+\mathrm{dAT}\end{array}$ & dDNA & dAT & None \\
\hline $\begin{array}{l}\text { Anti-dsDNA-positive } \\
-\begin{array}{l}\text { systemic lupus } \\
\text { erythematosus }\end{array}\end{array}$ & $41 / 50^{\mathrm{b}}$ & $7 / 50$ & $2 / 50$ & $0 / 50$ \\
$-\begin{array}{l}\text { non-systemic lupus } \\
\text { erythematosus }\end{array}$ & $33 / 37$ & $3 / 37$ & $1 / 37$ & $0 / 37$ \\
Anti-dsDNA-negative & $8 / 13$ & $4 / 13$ & $1 / 13$ & $0 / 13$ \\
\hline
\end{tabular}

a dsDNA, double stranded DNA; dDNA, denatured DNA; dAT, poly[dA-dT] double stranded alternating copolymer.

b No. of positives/No. tested.

\section{Discussion}

By using an ELISA format for the anti-dsDNA antibodies based on S1-nuclease-treated antigen (15), we were able to confirm the literature data on the reactivity of systemic lupus erythematosus and non-systemic lupus erythematosus sera to dsDNA $(1-4)$. The specificity of the assay in a group of anti-nuclear antibodypositive patients was $82 \%$, and after including antinuclear antibody-negative control sera the overall specificity was $91 \%$. The assay was positive in 48 of 71 patients with both active and inactive systemic lupus erythematosus (including three patients with systemic lupus erythematosus complicated with rheumatoid arthritis and/or vasculitis), reaching a sensitivity of $66 \%$, which is comparable to that reported in previous studies $(1-4,15)$. As observed previously $(4,15)$, a rather high proportion of non-systemic lupus erythematosus sera $(27.6 \%)$ also gave a positive reaction to dsDNA. Although non-systemic lupus erythematosus showed weaker binding to dsDNA, the difference was not significant.

The question, however, arises as to whether this nonsystemic lupus erythematosus dsDNA binding represents a false result due to the presence of single strands in our dsDNA preparation. Although we cannot rule out this possibility, it is interesting to note that a positive dsDNA finding in systemic lupus erythematosus and non-systemic lupus erythematosus patients was paralleled by dAT binding, an antigen that is apparently free of ssDNA strands (10). In addition, 3 of 24 anti-dsDNAnegative sera from various non-systemic lupus erythematosus immune-related diseases bound $\mathrm{dDNA}$ and $\mathrm{dAT}$, a finding that strongly argues against the presence of single strands in our dsDNA preparation. Radioimmunoassay showed a strong correlation between the binding of sera to ss-nuclease-treated natural DNA and to dAT (10). This correlation disappeared when ssnuclease-untreated natural DNA was used, indicating a contamination of native, nuclease-untreated DNA with ssDNA (10). It was also hypothesised that nucleasetreated dsDNA and dAT displayed antigenic similarity which resulted in high correlation of binding of antidsDNA-positive sera to both antigens. On the basis of these experiments it was concluded that synthetic antigens such as dAT might offer practical advantages over natural DNA preparations in detecting anti-dsDNA, since it contained most of the native DNA specificity (10). However, others have presented evidence that systemic lupus erythematosus sera contain a mixture of antibodies against different DNA epitopes, one population binding solely to dsDNA and another to dAT (reviewed in 1. c. (11)). Our results, obtained in an ELISA solidphase, assay, corroborate the finding of high correlation between the binding of anti-dsDNA-positive sera to $\mathrm{dAT}$, but stress again that the binding was not $100 \%$ 
complementary. In support of this view and in contrast to the findings of Steinman (10), we actually observed $\mathrm{dAT}$ binding in a proportion $(16.7 \%)$ of non-systemic lupus erythematosus ssDNA-positive sera from patients with rheumatoid arthritis and "mixed collagenosis". This observation further corroborates the heterogeneous pattern of individual anti-DNA specificity, as observed previously $(10-11)$. It should be noted that the differences observed might be associated with disease activity, since dAT binding was mainly observed in patients with active, but not with inactive nephritis (10). Our

\section{References}

1. Stollar BD. Immunochemistry of DNA. Int Rev Immunol 1989; 5:1-22.

2. Stollar BD. Anti-DNA antibodies. Clin Immunol Allergy 1981; 1:243-60.

3. Eaton BR, Schneider G, Schur PH. Enzyme immunoassay for antibodies to native DNA. Specificity and quality of antibodies. Arthritis Rheum 1983; 26:52-61.

4. Tan EM. Antinuclear antibodies: diagnostic markers for autoimmune diseases and probes for cell biology. Adv Immunol 1989; 44:93-151.

5. Steinberg AD, Krieg AM, Gourley MF, Klinman DM. Theoretical and experimental approaches to generalized autoimmunity. Immunol Rev 1990; 118:129-63.

6. Buskila D, Shoenfeld Y. Anti-DNA antibodies. In: Lahita RG, editor. Systemic lupus erythematosus. New York: Churchill Livingstone 1992:205-26.

7. Staines NA. Autoantibodies against DNA. In: Panayi GS, editor. Immunology of connective tissue diseases. Dordrecht: Kluwer Academic Publishers 1994:257-78.

8. Morgan A, Buchanan RRC, Lew AM, Olsen I, Staines NA. Five groups of antigenic determinants on DNA identified by monoclonal antibodies from $(\mathrm{NZB} \times \mathrm{NZW}) \mathrm{F}_{1}$ and $\mathrm{MRL} / \mathrm{lpr} /$ lpr mice. Immunology 1985;55:75-83.

9. Smeenk R, Hylkema M. Detection of antibodies to DNA: a technical assessment. Mol Biol Rep 1992; 17:71-9.

10. Steinman RC, Deesomchok U, Spiera H. Detection of antiDNA antibody using synthetic antigens. Characterization and current work is aimed at the comparison of binding of isolated anti-dsDNA antibodies from patients with systemic lupus erythematosus and non-systemic lupus erythematosus patients to dAT in the context of disease activity.

\section{Acknowledgements}

We thank Dr. Željko Bošnjak from the Laboratory of Cellular Biology, Medical College of Wisconsin, USA, for his continuous support in the form of chemicals and literature, and Mrs. Nives Radić for excellent technical assistance. clinical significance of binding of poly(deoxyadenylate-deoxythymidylate) by serum. J Clin Invest 1976; 57:1330-41.

11. Tan EM. Autoantibodies to nuclear antigens (ANA): their immunobiology and medicine. Adv Immunol 1982; 33:167-240.

12. Tan EM, Cohen AS, Fries JF, Masi AT, McShane DJ, Rothfield NF, et al. The 1982. revised criteria for the classification of systemic lupus erythematosus. Arthritis Rheum 1982; 25:1271-7.

13. Arnett FC, Edworthy SM, Bloch DA, McShane DJ, Fries JF, Cooper NS, et al. The American Rheumatism Association 1987: Revised criteria for the classification of rheumatoid arthritis. Arthritis Rheum 1987; 31:315-24.

14. Fox RI, Robinson CA, Curd JG, Kozin F, Howell FV. Sjögren's syndrome: proposed criteria for classification. Arthritis Rheum 1986; 29:577-85.

15. Rubin RL. Enzyme-linked immunosorbent assay for anti-DNA and anti-histone antibodies. In: Rose NR, Friedman H, Fahey $\mathrm{J}$, editors. Manual of clinical laboratory immunology. 3rd ed. Washington D.C.: American Society for Microbiology; 1986:744-9.

\section{Received January 23/December 6, 1995}

Corresponding author: Dr. Drago Batinić, Division of Immunology, Clinical Department of Laboratory Diagnosis, Clinical Hospital Center Zagreb, Kišpatićeva 12,

HR-10000 Zagreb, Croatia 
